\title{
Distribution and Diffusive Flux of Endogenous Nitrogen in an Urban Eutrophic Lake
}

\author{
Xin Li \\ Laboratory of Waterway Environmental Protection Technology, Tianjin Water Transport Engineering \\ Science Research Institute, Tianjin 300456, China
}

li1609xin@hotmail.com

\begin{abstract}
Keywords: Internal Nitrogen Release, Diffusive Flux, Oxidation Reduction Potential, Microbial Activity, Ammonification, Nitrification

Abstract. A field study was performed in an urban eutrophic lake of Tianjin to investigate the distribution and diffusive flux of nitrogen species. Dissolved organic nitrogen (DON), accounting for about $98 \%$ of total nitrogen (TN), was the dominant component in sediment. Ammonium $\left(\mathrm{NH}_{4}{ }^{+}-\mathrm{N}\right)$ was the main component of inorganic nitrogen in the sediment and the pore water while nitrate $\left(\mathrm{NO}_{3}{ }^{-}-\mathrm{N}\right)$ slightly exceeded $\mathrm{NH}_{4}{ }^{+}-\mathrm{N}$ in the overlying water. $\mathrm{NH}_{4}{ }^{+}-\mathrm{N} / \mathrm{DON}$ ratio had an obvious negative correlation with $\mathrm{Eh}$, temperature and FDA while $\mathrm{NO}_{3}{ }^{-}-\mathrm{N} / \mathrm{NH}_{4}{ }^{+}-\mathrm{N}$ had a positive correlation with those factors. Calculated by the Fick's First Law, the $\mathrm{NH}_{4}{ }^{+}-\mathrm{N}$ was the major nitrogen component in internal release with apparent diffusive tendency when $\mathrm{NO}_{3}{ }^{-}-\mathrm{N}$ mainly accumulated in the sediment. Obvious seasonal and spatial variations of nitrogen species and diffusion fluxes were observed. The plant area had lower $\mathrm{NH}_{4}{ }^{+}-\mathrm{N}$ and higher $\mathrm{NO}_{3}{ }^{-} \mathrm{N}$ than the center area due to weak reduction condition, which revealed that the anoxic condition played an important role in adsorption and immobilization of nitrogen by means of plant roots in internal release and also suggested the guidance mechanism for nitrogen nitrification and ammonification. In general, the surface sediment in eutrophic lakes, enriched by nitrogen, was the most active dimension for the biogeochemical cycling of nitrogen in which $\mathrm{NH}_{4}^{+}-\mathrm{N}$ was the major and most effective forms.
\end{abstract}

\section{Introduction}

In recent years, the global issue of eutrophication, especially the knowledge of nitrogen distribution and migration, has been greatly concerned due to their wide-spread [1,2]. This issue was critical in understanding the mechanism of nitrogen cycle and freshwater ecosystem responses to micro environmental factors and anthropogenic mediated change [3, 4]. Lake sediments were the main destinations as the storage pool of nutrients by diagenetic transformation when some endogenous nitrogen released from the sediment to the freshwater which led to eutrophic restoration under some conditions [5]. Some cases were mainly focused on the form, the content, the distribution and seasonal variations to study internal release of nitrogen in the sediments, while the others were in situ, including the profile of nitrogen cycle in vertical scale and the mechanism of combining the information and reduction of nitrogen species in mineralization, nitrification and denitrification [6-8].

In the sediment-water interface, the occurrence and distribution of nitrogen species was accurately understood by geochemical dynamics as well as some related influence factors [9]. For issues of internal nitrogen eutrophication in urban shallow lakes, the oxidation reduction potential (Eh) is the main micro environmental factor in the sediments [10]. Besides Eh, the temperature and microbial activity expressed by fluorescein-diacetate-ester (FDA) in which hydrolysis activity has significant positive correlation with the biomass were other primary influence factors [11]. However, the mutual relations between nitrogen releases mainly defined by the fluxes of ammonification and nitrification to these parameters had the uncertainties for further recognition.

The aim was to determine whether the removal or inhibit of endogenous nitrogen release affected by the temperature, the oxidation condition (Eh) and microbial activity and whether the ammonium $\left(\mathrm{NH}_{4}{ }^{+}-\mathrm{N}\right)$, nitrate $\left(\mathrm{NO}_{3}{ }^{-} \mathrm{N}\right)$ fluxes represented the most significant inhibition or correlation in lake sediments. The further aim was to provide scientific basis for describing the diffusion, the 
transportation and the migration in nitrogen release and to reveal the initial sediment biogeochemical cycle of nitrogen in place with the main regional mechanism for eutrophic restoration.

\section{Sample Collection and Analysis}

Samples were obtained from lake in the city of Tianjin. Lake is a typical shallow urban eutrophic lake that had no large stationary sources of pollution while the lake was subject to the discharge of sewage several years ago.

In the laboratory, within $12 \mathrm{~h}$ after the sample collection, the pore water was obtained by the centrifugal drainage technique from the fresh sediment. The pore water and overlying water was vacuum filtered by $0.45 \mu \mathrm{m}$ cellulose acetate membranes (Beijing N\&D Co. Ltd., China). After the moisture content determination, the fresh sediment samples were spread to be dried and then sieved through a 60 -mesh sieve for future testing. All of the treated samples were stored at $-4^{\circ} \mathrm{C}$.

Inorganic nitrogen species of ammonium, nitrate and nitrite were determined calorimetrically by UV-2800 ultraviolet spectrophotometer (Unicco Co. Ltd., China). Total nitrogen (TN) in water was determined by means of Persulfate Oxidation (PO) while its concentration in the sediment was monitored by the Kjedahl method. DON was calculated as the margin between the TN concentration and inorganic species concentration. Chlorophyll- $\alpha$ concentrations were determined by the typical method. The Eh value was measured by a platinum electrode following the national standardized method. The FDA content was monitored as follows: the surface sediment samples were determined calorimetrically at 490nm with added FDA solution and phosphate buffer. All reagents and chemicals were of analytic grade and all data were averaged from three measurements. The depth, $\mathrm{pH}$, turbidity and chlorophyll- $\alpha$ of the overlying water as well as the temperature and moisture content of the sediment in the two areas are shown in Table 1.

Table 1 Depth, temperature, $\mathrm{pH}$, turbidity, chl- $\alpha$ and moisture content in Lake

\begin{tabular}{ccccccc}
\hline & Depth $(\mathrm{m})$ & Temperature $\left({ }^{\circ} \mathrm{C}\right)$ & $\mathrm{pH}$ & Moisture content $(\%)$ & Turbidity $(\mathrm{NTU})$ & $\mathrm{Chl}-\alpha(\mu \mathrm{g} / \mathrm{L})$ \\
\hline Plant area & $1.7-2.2$ & $4.0-23.7$ & $7.8-8.5$ & $59-77$ & $61-70$ & $50.2-63.9$ \\
Centre area & $3.1-3.7$ & $5.1-19.2$ & $7.9-8.3$ & $51-63$ & $55-63$ & $31.2-44.8$ \\
\hline
\end{tabular}

\section{Results and Discussion}

The average concentrations of TN, DON, $\mathrm{NH}_{4}{ }^{+}-\mathrm{N}, \mathrm{NO}_{3}{ }^{-}-\mathrm{N}$ and $\mathrm{NO}_{2}{ }^{-}-\mathrm{N}$ in the pore water, overlying water and sediment in the plant area and the center area are shown in Table 2. The average concentrations of TN were 4344 and $4842 \mathrm{mg} / \mathrm{kg}$ in the plant area and the center area, respectively. Compared with other studies, concentration of TN was much higher than $1400 \mathrm{mg} / \mathrm{kg}$ in Lake Taihu, $600 \mathrm{mg} / \mathrm{kg}$ in Lake Chaohu, $2700 \mathrm{mg} / \mathrm{kg}$ in Lake Erhai and $2800 \mathrm{mg} / \mathrm{kg}$ in Lake Ontario, which reflected serious nitrogen eutrophication in lake.

Table 2 Average Concentration of Nitrogen Species in the Plant and Centre Area. (mg/kg)

\begin{tabular}{ccccccc}
\hline & \multicolumn{3}{c}{ Plant Area } & \multicolumn{3}{c}{ Centre Area } \\
& Sediment & Pore Water & Overlying Water & Sediment & Pore Water & Overlying Water \\
\hline $\mathrm{TN}$ & 4344 & 14.4 & 6.45 & 4842 & 17.26 & 6.57 \\
$\mathrm{NH}_{4}{ }^{+}-\mathrm{N}$ & 102.5 & 11.13 & 0.90 & 151.7 & 13.94 & 0.88 \\
$\mathrm{NO}_{3}{ }^{-} \mathrm{N}$ & 5.48 & 0.21 & 1.24 & 4.53 & 0.27 & 1.24 \\
$\mathrm{NO}_{2}{ }^{-}-\mathrm{N}$ & 1.93 & -- & 0.09 & 1.61 & -- & 0.1 \\
$\mathrm{DON}$ & 4254 & 3.06 & 4.32 & 4729 & 3.06 & 4.45 \\
\hline
\end{tabular}

DON was the main nitrogen species in two areas, accounting for more than $90 \%$ in the sediment and $60 \%$ in the overlying water. However, $\mathrm{NH}_{4}{ }^{+}-\mathrm{N}$, almost $80 \%$ of TN, was the major nitrogen in the pore water. Nitrogen diffusion generally occurred from the high concentration to the low concentration in sediment-water interface. DON concentrations in the overlying water ranged be-tween the pore water and the sediment which revealed that DON would not spread from the sediment to the overlying water directly.

For inorganic nitrogen, $\mathrm{NH}_{4}{ }^{+}-\mathrm{N}$ was the major component in the sediment and the pore water while $\mathrm{NO}_{3}{ }^{-}-\mathrm{N}$ slightly exceeded $\mathrm{NH}_{4}{ }^{+}-\mathrm{N}$ in the overlying water. This result could be explained by nitrogen 
releasing dynamics: due to the anaerobic conditions, the ammonification of DON ammoniated to $\mathrm{NH}_{4}{ }^{+}-\mathrm{N}$ was accelerated and nitrification that $\mathrm{NH}_{4}{ }^{+}-\mathrm{N}$ nitrified to $\mathrm{NO}_{3}{ }^{-}-\mathrm{N}$ was inhibited. It resulted in the accumulation of $\mathrm{NH}_{4}{ }^{+}-\mathrm{N}$ in the sediment. Furthermore, the external input led to higher $\mathrm{NO}_{3}{ }^{-} \mathrm{N}$ concentration in the overlying water than those in the pore water. The instability of $\mathrm{NO}_{2}^{-}-\mathrm{N}$ in ammonification, nitrification and denitrification could explain why $\mathrm{NO}_{2}^{-}-\mathrm{N}$ was the minimum inorganic nitrogen species.

The average concentrations of $\mathrm{TN}, \mathrm{DON}$ and $\mathrm{NH}_{4}{ }^{+} \mathrm{N}$ in the plant area were lower than in the center while $\mathrm{NO}_{3}{ }^{-} \mathrm{N}$ in the sediments was on the contrary higher in plant area than that in center area. It is suggested that the plant roots and microbial activity promoted the conversion of organic nitrogen to inorganic species by ammonification, especially in reeds and Ceratophyllum prosperity. Due to the loose condition of the sediment induced by root immobilization, enhanced nitrification led to higher $\mathrm{NO}_{3}{ }^{-} \mathrm{N}$ in the plant area that can be explained by the mitigated hypoxia status and principle in which the nitrification was limited by less oxygen penetration in the sediments.

Seasonal variations of TN, DON, $\mathrm{NH}_{4}{ }^{-}-\mathrm{N}$ and $\mathrm{NO}_{3}{ }^{-} \mathrm{N}$ are given in Figure 1. The plant area and center area had a similar variation tendency and almost all of the nitrogen species in the plant area had larger amplitude than in the center area. TN and DON in the sediment had maximum concentration in April and minimum concentration in September. TN and DON gradually decreased gradually from April to September but increased from February to April. The phenomenon might be explained by DON degradation in spring and summer and an accumulation in autumn and winter. However, compared with DON in the pore water and the overlying water, there were no regular gradient differences in two phases. The external input of DON might be the main reason for this phenomenon. The $\mathrm{NH}_{4}{ }^{+}-\mathrm{N}$ in three phases had similar tendency with obvious gradient differences. It is shown that $\mathrm{NH}_{4}{ }^{+}-\mathrm{N}$ in the sediment had great effect to its content in the pore water and the overlying water. Referring to other cases for $\mathrm{NH}_{4}{ }^{+}-\mathrm{N}$ release, these changes might be induced by the weak reduction condition with the rising Eh which inhibited the ammonification and enhanced nitrification. The variability of the rising $\mathrm{NO}_{3}{ }^{-} \mathrm{N}$ in the sediment further confirmed this process.
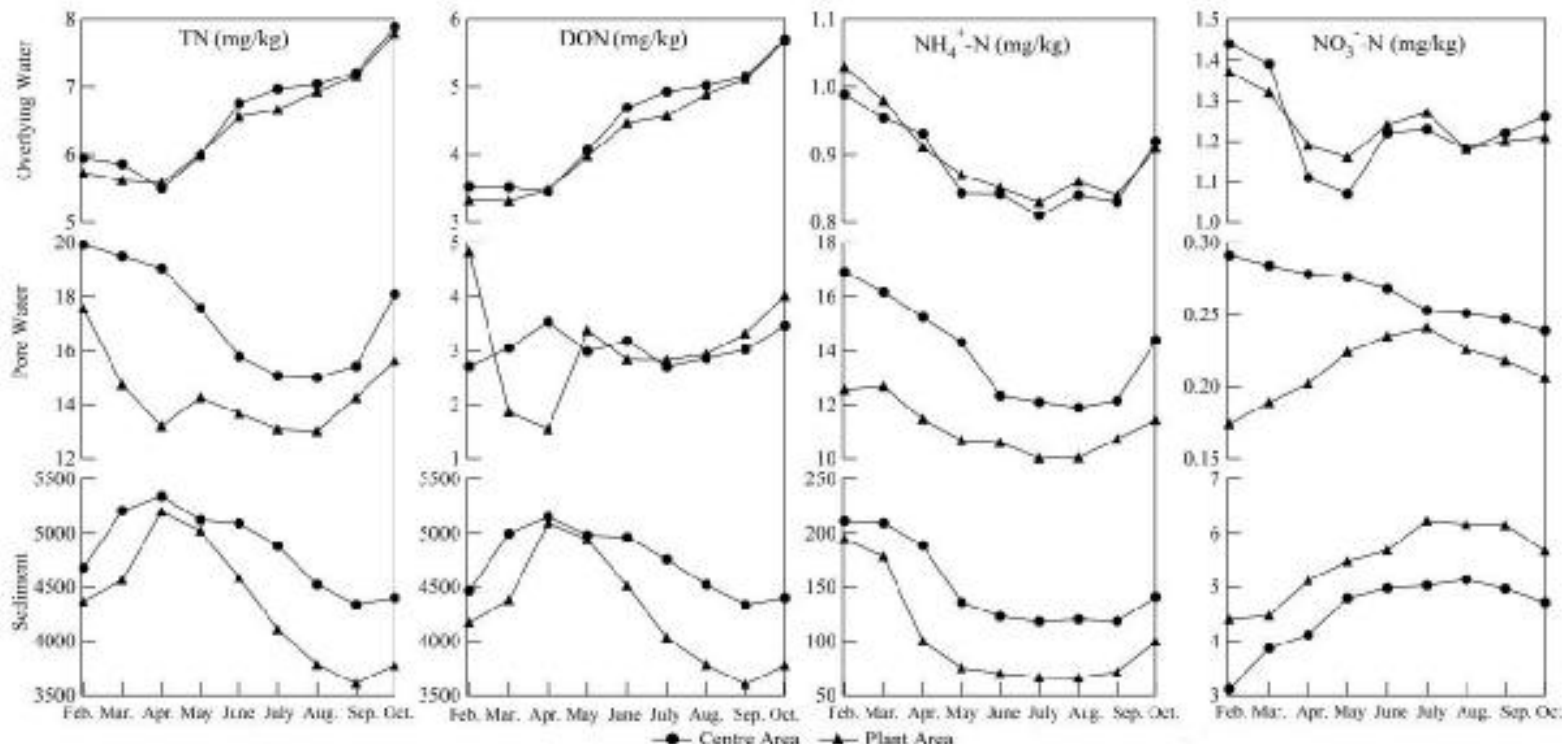

Fig 1 Seasonal Variations of Nitrogen Species in Two Areas

The fluxes of $\mathrm{NH}_{4}{ }^{+}-\mathrm{N}$ and $\mathrm{NO}_{3}{ }^{-}-\mathrm{N}$ can be indicators for the sink and source of nitrogen release in sediment-water interface. The fluxes in sediment-water interface were calculated by the formulas based on Fick's First Law. The diffusive flux was subjected to the factors of concentration gradient, the sediment porosity in sediment-water interface and the particle impedance factor on nitrogen diffusion. Therefore, the $\mathrm{NH}_{4}{ }^{+}-\mathrm{N}$ and $\mathrm{NO}_{3}{ }^{-} \mathrm{N}$ fluxes were slightly larger in theory than those in actual testing by the bioturbation.

Fluxes estimates for $\mathrm{NH}_{4}{ }^{+}-\mathrm{N}$ and $\mathrm{NO}_{3}{ }^{-}-\mathrm{N}$ in two areas are given in Figure 2. The $\mathrm{NH}_{4}{ }^{+}-\mathrm{N}$ flux ranged from $12.4 \mathrm{mg} \cdot \mathrm{m}^{-2} \cdot \mathrm{d}^{-1}$ to $17.4 \mathrm{mg} \cdot \mathrm{m}^{-2} \cdot \mathrm{d}^{-1}$ in two areas which con-firmed an apparent diffusive 
tendency from the sediment to the overlying water. However, the $\mathrm{NO}_{3}{ }^{-} \mathrm{N}$ flux was negative which indicated that $\mathrm{NO}_{3}{ }^{-} \mathrm{N}$ accumulated in the sediment. These results suggest that the inorganic species were a main form of internal release and $\mathrm{NH}_{4}{ }^{+}-\mathrm{N}$ was the main release component in the sediments.

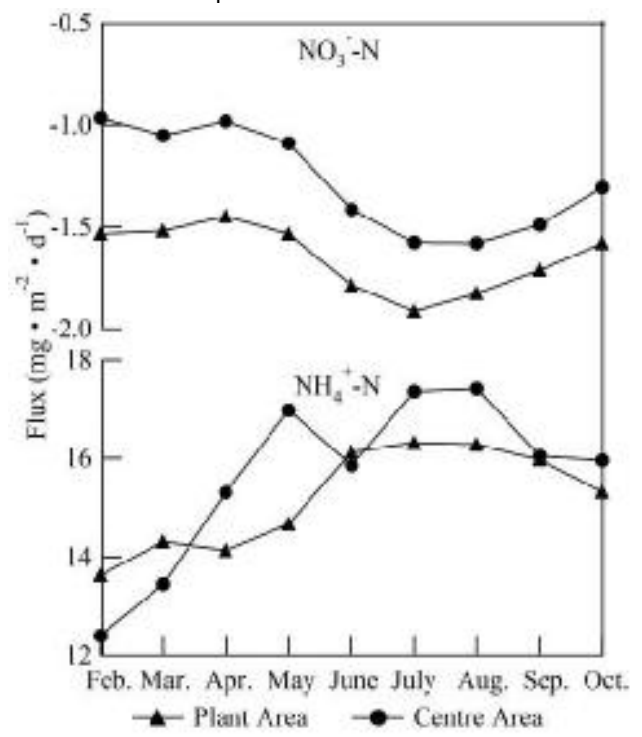

Fig 2 Diffusive Fluxes of $\mathrm{NH}_{4}{ }^{+}-\mathrm{N}$ and $\mathrm{NO}_{3}{ }^{-} \mathrm{N}$ in Plant Area and Center Area

From February to July, the $\mathrm{NH}_{4}{ }^{+}-\mathrm{N}$ and $\mathrm{NO}_{3}{ }^{-}-\mathrm{N}$ diffusion rates had a similar increase tendency. A reasonable explanation is that expansion of the plant roots, microbial activity and the loose surface sediment with new coverage of organism led to the increase tendency of sediment porosity and further strengthened the diffusive flux.

Seasonal dynamics of Eh, the temperature and FDA are shown in Figure 3. These three factors had similar seasonal variation tendency in two areas although they had visible divergence. Eh was no more than $200 \mathrm{mv}$ which rendered the reduction condition. FDA had positive correlation with Eh $(\mathrm{R}=0.813)$ which indicated that the aerobic bacteria adapted in weak reduction condition and was the major microbe in the surface sediments. FDA had stronger correlation with temperature $(\mathrm{r}=0.892)$ than Eh $(r=0.813)$ reflecting that temperature had greater influence to microbial activity. The correlation among Eh, the temperature and FDA were positive and Eh in the plant area was slightly higher than in the center area. These results suggested that the photosynthesis by the plant roots was more susceptible and the root parasitizing in the sediment caused more microbial activity as they caused the weak reduction condition.

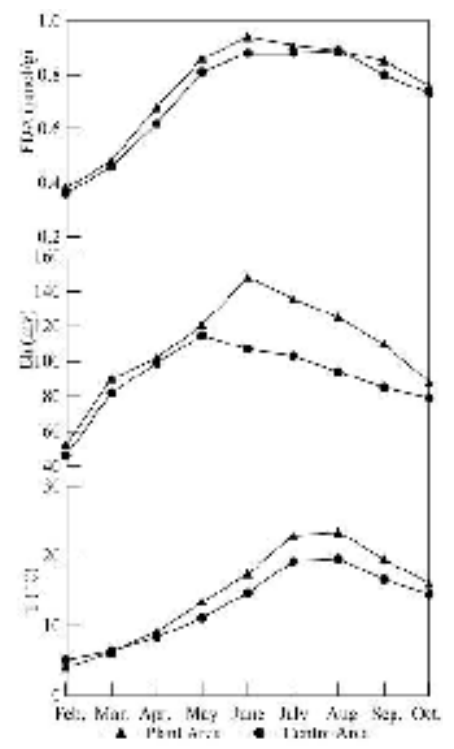

Fig 3 Seasonal Dynamics of Eh, $\mathrm{T}$ and FDA in Lake

The $\mathrm{NH}_{4}{ }^{+}-\mathrm{N} / \mathrm{DON}$ mass ratios and $\mathrm{NO}_{3}{ }^{-}-\mathrm{N} / \mathrm{NH}_{4}{ }^{+}-\mathrm{N}$ mass ratios can reflect ammonification and nitrification rates, respectively. The two rates also had correlations with the microbial activity, the 
temperature and sediment oxygen conditions. Thus, they may have great influence on the two ratios especially in the nitrification.

The correlation between $\mathrm{NH}_{4}{ }^{+}-\mathrm{N} / \mathrm{DON}$ and $\mathrm{NO}_{3}{ }^{-} \mathrm{N} / \mathrm{NH}_{4}{ }^{+}-\mathrm{N}$ to $\mathrm{T}$, Eh and FDA are shown in Figure 4. $\mathrm{NH}_{4}{ }^{+}-\mathrm{N} / \mathrm{DON}$ ratio showed a good negative correlation with Eh which indicated that the ammonification rate de creased along with the reduction condition weakening in the sediment. It indicated that the ammonification was prone to reaction under anaerobic conditions. It is reported that the activity of amination bacteria increased with rising temperature in nature condition. The temperature and FDA also had obvious negative correlation with $\mathrm{NH}_{4}{ }^{+}-\mathrm{N} / \mathrm{DON}$. Therefore, it can be concluded that the redox potential in the sediment was an important factor for the ammonification. The correlation of the temperature and microbial activity to the ammonification should be positive. However, the study got an opposite conclusion. A plausible explanation was that the weak reduction condition in the sediment was the decisive factor for ammonification.

The correlation coefficient among Eh, T and FDA with $\mathrm{NO}_{3}{ }^{-}-\mathrm{N} / \mathrm{NH}_{4}{ }^{+}-\mathrm{N}$ ratio showed significant positive correlations which indicated that they could promote the nitrification which was prone to the reaction with oxidization condition. The $\mathrm{NO}_{3}{ }^{-}-\mathrm{N} / \mathrm{NH}_{4}{ }^{+}-\mathrm{N}$ ratio ranged from $1.47 \%$ to $9.35 \%$ with the rising temperature. The $\mathrm{NH}_{4}{ }^{+}-\mathrm{N} / \mathrm{DON}$ ratio ranged from $1.52 \%$ to $4.72 \%$. It revealed that the nitrification was sensitively affected by the micro environmental parameters. Figure 4 illustrated that the nitrification in the plant area was significantly larger than that in the center area which demonstrated that the plants could promote nitrification with higher Eh by roots photosynthesis in the sediment.
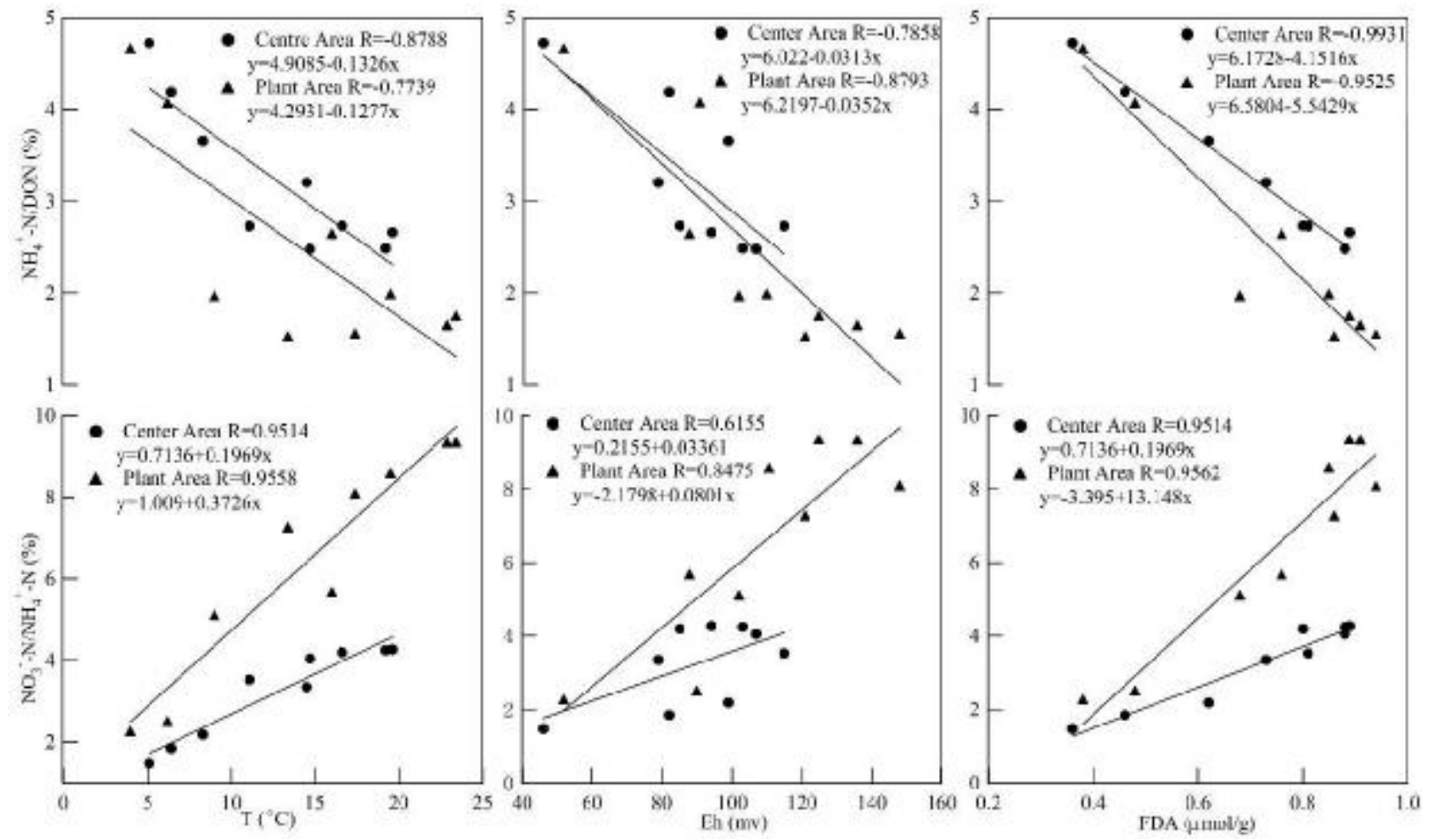

Fig 4 Linear correlation between $\mathrm{NH}_{4}{ }^{+}-\mathrm{N} / \mathrm{DON}$ and $\mathrm{NO}_{3}{ }^{-}-\mathrm{N} / \mathrm{NH}_{4}{ }^{+}-\mathrm{N}$ to $\mathrm{T}$, Eh and FDA

\section{Conclusions}

Compared with domestic and aboard studies, TN in the sediments was significantly greater than the general level which illustrated the serious eutrophication in Lake. DON was the main form in the sediment and $\mathrm{NH}_{4}{ }^{+}-\mathrm{N}$ was the major nitrogen component in internal release in sediment-water interface. Meanwhile, $\mathrm{NO}_{3}{ }^{-}-\mathrm{N}$ was the sink of external input in the sediment. The plant area had lower $\mathrm{NH}_{4}{ }^{+}-\mathrm{N}$ concentrations and higher $\mathrm{NO}_{3}{ }^{-}-\mathrm{N}$ concentrations than the center area due to the weak reduction condition by the plant prosperity which promoted the process of the nitrification and inhibited ammonification in the sediments. It quantitatively decrypted the nitrogen internal release by the calculation of diffusive flux. $\mathrm{NH}_{4}{ }^{+}-\mathrm{N} / \mathrm{DON}$ ratio had obvious negative correlation with Eh, $\mathrm{T}$ and 
FDA and the rising Eh was the primary factor of ammonification inhibition. The $\mathrm{NO}_{3}{ }^{-} \mathrm{N} / \mathrm{NH}_{4}{ }^{+}-\mathrm{N}^{-}$had positive correlation with the three factors. The amplitude of $\mathrm{NH}_{4}{ }^{+}-\mathrm{N} / \mathrm{DON}$ ratio was moderate but the amplitude of $\mathrm{NO}_{3}{ }^{-} \mathrm{N} / \mathrm{NH}_{4}{ }^{+}-\mathrm{N}$ was great. Meanwhile, the correlation coefficient between the parameters with $\mathrm{NO}_{3}{ }^{-} \mathrm{N} / \mathrm{NH}_{4}{ }^{+}-\mathrm{N}$ in the plant area was more sensitive than in the center area. It verified that the nitrification, rather than the ammonification, was more sensitively affected by redox conditions in the sediments..

\section{Acknowledgements}

This work was supported by the Research of "Study of foreign soil water retention, prevent salinization, heavy metal soil remediation, soil backfill and ecological restoration technique in land reclamation. (TKS150218).

\section{References}

[1] Smith, V.H. Eutrophication of freshwater and coastal marine ecosystems [J]. Environmental Science and Pollution Research, 2003, 10 (2), p.126

[2] Pavlidou, A., Kontoyiannis, H. and Psyllidou-Giouranovits. Trophic conditions and stoichiometric nutrient balance in the inner Saronikos Gulf (Central Aegean Sea) affected by the Psittalia sewage outfall [J]. Fresenius Environmental Bulletin, 2004, 13 (12b), p.1509

[3] Vitousek, P.M., Aber, J.D., Howarth, R.W., Likens, G.E. Human alteration of the global nitrogen cycle: sources and consequences [J]. Ecological Applications, 1997, 7 (3), p.737

[4] Keeney, D.R. The nitrogen cycle in sediment-water systems [J]. Journal of Environmental Quality, 1977, 2, p.15

[5] Galloway, J.N., Dentener, F.J., Capone, D.G., Boyer, E.W. Nitrogen cycles: past, present, and future [J]. Biogeochemistry, 2004, 70 (2), p.153

[6] Kemp, A.L. and Muckochova, A.A. Distribution and forms of nitrogen in a Lake Ontario sediment core [J]. Limnology and Oceanology, 1997, 17 (6), p.855

[7] Wang, G.X., Pu, P.M., Huang, Y.K. and Zhang, S.Z. Distribution and role of denitrifying, nitrifying, nitration and ammonifying bacteria in the Taihu Lake [J]. Chinese Journal of Applied and Environmental Biology, 2207, 5 (2), p.190

[8] Chen, G.Y., Li, J.Q., Li, Q.M. and Zhou, Y.Y. Different forms of nitrogen contents and their vertical variations of transformation modes of the sediments of Lake Yuehu, Wuhan [J]. Journal of Lake Science, 2004, 20 (4), p.463

[9] Bolałek, J. and Graca, B. Ammonia nitrogen at the water-sediment interface in Puck Bay (Baltic Sea) [J]. Estuarine, Coastal and Shelf Science, 2004, 43, p.767

[10] Hu, Q.H., Zhu, Y.M., Song, J., Li, Z.Y. and Wen, J.J. Effects of pH and Eh on release of nitrogen and phosphorus from sediments of West Lake [J]. Journal of Zhejiang University Science A, 2004, 4 (3), p.358

[11] Yukiko, S., Mikiya, H., Yosuke, N.,Yasushi, W., Yasunori, W. and Seiichi, N. Vertical profiles of DIN, DOC, and microbial activities in the wetland soil of Kushiro Mire, northeastern Japan [J]. Limnology, 2011, 12, p.17 